\title{
NADPH Oxidase Activity and Reactive Oxygen Species Production in Brain and Kidney of Adult Male Hypertensive Ren-2 Transgenic Rats
}

\author{
M. VOKURKOVÁ ${ }^{1}$, H. RAUCHOVÁ ${ }^{1}$, L. ŘEZÁČOVÁ ${ }^{1}$, I. VANĚČKOVÁ $^{1}$, J. ZICHA $^{1}$ \\ ${ }^{1}$ Institute of Physiology, Czech Academy of Sciences, Prague, Czech Republic
}

Received November 5, 2015

Accepted November 18, 2015

\begin{abstract}
Summary
Hypothalamic paraventricular nucleus (PVN) and rostral ventrolateral medulla (RVLM) play an important role in brain control of blood pressure (BP). One of the important mechanisms involved in the pathogenesis of hypertension is the elevation of reactive oxygen species (ROS) production by nicotine adenine dinucleotide phosphate (NADPH) oxidase. The aim of our present study was to investigate NADPH oxidase-mediated superoxide $\left(\mathrm{O}_{2}{ }^{-}\right)$production and to search for the signs of lipid peroxidation in hypothalamus and medulla oblongata as well as in renal medulla and cortex of hypertensive male rats transgenic for the murine Ren-2 renin gene (Ren-2 TGR) and their age-matched normotensive controls - Hannover Sprague Dawley rats (HanSD). We found no difference in the activity of NADPH oxidase measured as a lucigenin-mediated $\mathrm{O}_{2}^{-}$production in the hypothalamus and medulla oblongata. However, we observed significantly elevated NADPH oxidase in both renal cortex and medulla of Ren-2 TGR compared with HanSD. Losartan (LOS) treatment (10 mg/kg body weight/day) for 2 months (Ren-2 TGR+LOS) did not change NADPH oxidase-dependent $\mathrm{O}_{2}^{-}$ production in the kidney. We detected significantly elevated indirect markers of lipid peroxidation measured as thiobarbituric acid-reactive substances (TBARS) in Ren-2 TGR, while they were significantly decreased in Ren-2 TGR+LOS. In conclusion, the present study shows increased NADPH oxidase activities in renal cortex and medulla with significantly increased TBARS in renal cortex. No significant changes of NADPH oxidase and markers of lipid peroxidation were detected in the studied brain regions.
\end{abstract}

\section{Key words}

Paraventricular nucleus • Rostral ventrolateral medulla • Renal medulla $\bullet$ Renal cortex $\bullet$ Oxidative stress $\bullet$ Lipid peroxidation

\section{Corresponding author}

H. Rauchová, Institute of Physiology, Czech Academy of Sciences, Vídeňská 1083, 14220 Prague 4, Czech Republic. Fax: +420 24106 2488. E-mail: Hana.Rauchova@fgu.cas.cz

\section{Introduction}

Neurogenic basis of hypertension is accepted in both humans and various animal models. Two relevant centers of arterial blood pressure (BP) control in the brain are the hypothalamic paraventricular nucleus (PVN) and rostral ventrolateral medulla (RVLM) (Guyenet 2006, Gabor and Leenen 2012). Numerous studies described the elevation of reactive oxygen species (ROS) production as one of the important mechanisms involved in the pathophysiology of hypertension (Peterson et al. 2006, Harrison and Gongora 2009, Hirooka et al. 2011, Chan and Chan 2014). One of the major sources of cellular ROS is multicomponent plasma membrane nicotinamide adenine dinucleotide phosphate (NADPH) oxidase (Griendling et al. 2000). The augmentation of oxidative stress through increased NADPH oxidase-mediated $\mathrm{O}_{2}{ }^{-}$ production has also been reported in the pathogenesis of hypertension (Paravicini and Touyz 2008, Datla and Griendling 2010). Our previous study performed in adult salt hypertensive Dahl rats showed neither the increased activity of NADPH oxidase-mediated $\mathrm{O}_{2}{ }^{-}$production nor the increased levels of markers of lipid peroxidation damage in hypothalamus or medulla oblongata (Vokurková et al. 2015). However, we found the enhanced NADPH oxidase-mediated $\mathrm{O}_{2}^{-}$production (without significant increase of lipid peroxidation) in the renal medulla of salt hypertensive Dahl sensitive rats.

The renin-angiotensin system is a powerful 
biological modulator of mammalian BP. Its dysregulation causes hypertension, whereas its pharmacological blockade by direct renin inhibitors, angiotensinconverting enzyme inhibitors or angiotensin receptor blockers lowers BP (Crowley and Coffman 2014). A well-defined monogenetic model of angiotensin IIdependent hypertension is adult male heterozygous Ren-2 transgenic rats (Ren-2 TGR). In this strain murine Ren-2 gene was inserted into the genome of normotensive Hannover Sprague Dawley rats (HanSD) and reninangiotensin system (RAS) was inappropriately activated (Mullins et al. 1990). Angiotensin II is known to stimulate ROS production by NADPH oxidase (Nguyen Dinh Cat et al. 2013).

The aim of our present study was to investigate NADPH oxidase-mediated $\mathrm{O}_{2}^{-}$production and to search for the enhancement of lipid peroxidation in hypothalamus and medulla oblongata as well as renal medulla and renal cortex of Ren-2 and HanSD rats. We also studied whether angiotensin II type 1 receptor antagonist, losartan (LOS), which normalizes BP in this model, could attenuate NADPH oxidase-mediated $\mathrm{O}_{2}{ }^{-}$ production and lipid peroxidation in the above mentioned tissues.

\section{Material and Methods}

\section{Reagents}

Nicotinamide-adenine dinucleotide phosphate (NADPH), ethylene glycol-bis(2-amino-ethylether)N,N,N',N'-tetraacetic acid (EGTA), aprotinin, leupeptin, pepstatin, phenylmethylsulfonyl fluoride, 1,1,3,3tetraethoxypropane, lucigenin (9, 9'-bis[N-methyl acridinium nitrate] and Folin reagent were purchased from Sigma-Aldrich Co (USA), Lubrol from Serva (Germany) and losartan (Lozap) from Zentiva (Czech Republic). All other reagents were of the purest grade commercially available.

\section{Animals}

Twenty 4-week-old male heterozygous Ren-2 transgenic rats and 10 age-matched transgene-negative normotensive Hannover Sprague Dawley rats were used for our experiments. All animals were housed under standard laboratory conditions (temperature $23 \pm 1{ }^{\circ} \mathrm{C}$, 12-h light/dark cycle) in the facility of Institute of Physiology accredited by the Czech Association of Laboratory Animal Care and maintained on tap water and standard rodent chow (Altromin) ad libitum.

\section{Antihypertensive regime}

From the age of 4 weeks 10 randomly chosen Ren-2 TGR were given tap water containing $100 \mathrm{mg} / \mathrm{l}$ of losartan, i.e. $10 \mathrm{mg} / \mathrm{kg} /$ day (Ren-2 TGR+LOS) for 2 months similarly as in our previous study (Rakušan et al. 2010). All procedures and experimental protocols in the experimental animals, which were approved by the Ethical Committee of the Institute of Physiology CAS, conform to the European Convention on Animal Protection and Guidelines on Research Animal Use.

\section{Monitoring of systolic blood pressure}

Systolic blood pressure (SBP) was measured by automated tail-plethysmography system MC 4000; Hatteras, North Carolina, USA (ERDF, OPPK Biomodels CZ.2.16/3.1.00/24017). To eliminate the influence of circadian SBP variation, the measurements were always done approximately at the same time of day (between 8:00 and 10:00 a.m.).

\section{Sample preparation}

At the end of the experiment, the animals subjected to ether anesthesia were euthanized by decapitation. The heart and kidney were removed and weighted. The brain was quickly removed from the scull on ice-cold platform. The macroscopic structures of the brainstem (without cerebellum) were manually separated in two parts according to a rat brain atlas (Paxinos and Watson 2005). Part A means hypothalamus including PVN and part B medulla oblongata with pons including RVLM (AP -9 to AP -15). The mean weights of the individual blocks of brain tissue $( \pm$ SEM) were $61 \pm 2.1$ and $176 \pm 2.3 \mathrm{mg}$ for parts $\mathrm{A}$ and $\mathrm{B}$, respectively. The dissected parts of the brain were homogenized in $10 \%$ (wt/vol) ice-cold lysis buffer containing $20 \mathrm{mmol} / \mathrm{l}$ $\mathrm{KH}_{2} \mathrm{PO}_{4}, 1 \mathrm{mmol} / \mathrm{l}$ EGTA, $1 \mu \mathrm{g} / \mathrm{ml}$ aprotinin, $1 \mu \mathrm{g} / \mathrm{ml}$ leupeptin, $1 \mu \mathrm{g} / \mathrm{ml}$ pepstatin, $1 \mathrm{mmol} / 1$ phenylmethylsulfonyl fluoride ( $\mathrm{pH}$ 7.4) and placed on ice. Folin method was used for the determination of protein concentration in the homogenates using bovine serum albumin as standard (Lowry et al. 1951).

\section{Measurement of lipid peroxidation}

Lipid peroxidation in the frozen-thawed samples was measured by measuring thiobarbituric acid-reactive substances (TBARS) formation (Ohkawa et al. 1979). To determine TBARS, the brain homogenates were incubated with thiobarbituric and acetic acid at $95^{\circ} \mathrm{C}$ for $45 \mathrm{~min}$. After cooling the developed fluorescent 
substance was extracted with n-butanol. Fluorescence of the organic phase was measured at an excitation wavelength of $515 \mathrm{~nm}$ and an emission wavelength of $553 \mathrm{~nm}$ using Tecan Infinite M200 multimode microplate fluorometer. A calibration curve was prepared from 1,1,3,3-tetraethoxypropane. The results were expressed as nmol of TBARS per mg of protein.

\section{Determination of conjugated dienes}

The concentration of conjugated dienes (CD) was determined in freshly isolated lipid extracts of brain part B, renal cortex and medulla and heart homogenates. Briefly, homogenates were extracted in a chloroformmethanol (1:1) mixture. After organic solvent evaporation under nitrogen atmosphere, the lipid residues were dissolved in cyclohexane and determined spectrophotometrically at $233 \mathrm{~nm}$ according to previously described method (Kogure et al. 1982).

Samples of brain and kidney frozen-thawed homogenate $(0.010-0.020 \mathrm{mg}$ of protein) were added to $1 \mathrm{ml}$ of $10 \mathrm{mmol} / 1$ phosphate buffer $(\mathrm{pH} 7.4)$ with $1 \%$ (wt/vol) Lubrol. Formation of conjugated dienes was measured from the absorbance ratio $\mathrm{A}_{233} / \mathrm{A}_{215}$ (oxidative index) using a spectrophotometer Beckman DU-7 (Klein 1970, Kaplán et al. 2000).

\section{Measurement of NADPH oxidase activity}

The lucigenin-enhanced chemiluminescence assay was used to determine NADPH oxidase-mediated superoxide radical $\left(\mathrm{O}_{2}^{-}\right)$production in the two parts of freshly isolated brain and renal medulla and cortex homogenates (Matsui et al. 2006). The reaction was started by the addition of NADPH $(0.1 \mathrm{mmol} / \mathrm{l})$ to the suspension $(250 \mu \mathrm{l}$ final volume) containing assay phosphate buffer $\left(50 \mathrm{mmol} / 1 \mathrm{KH}_{2} \mathrm{PO}_{4}, 1 \mathrm{mmol} / \mathrm{l}\right.$ EGTA, $150 \mathrm{mmol} / 1$ sucrose, $\mathrm{pH} 7.4$ ), sample and lucigenin (5 $\mu \mathrm{mol} / \mathrm{l})$. The luminescence was measured using Tecan Infinite M200 multimode microplate fluorometer at $30{ }^{\circ} \mathrm{C}$ every $5 \mathrm{~s}$ for 10 and $3 \mathrm{~min}$, in brain and kidney homogenates, respectively (Fig. 1). Buffer blank was subtracted from each reading. The activity of NADPH oxidase was expressed as counts per mg protein.

\section{Determination of thiol concentrations}

he intracellular content of reduced glutathione (GSH) in the renal cortex, heart and liver was determined according to the method described earlier (Ellman 1959). Briefly, the tissue samples were homogenized in $3 \%$ sulfosalicylic acid and $10 \%$ homogenates were centrifuged for $10 \mathrm{~min}$ at $3000 \mathrm{~g}$. A portion of the supernatant was mixed with $0.02 \mathrm{M} \mathrm{5,5}$ '-dithiobis-(2nitrobenzoic acid) in $0.1 \mathrm{M}$ phosphate buffer $(\mathrm{pH} 8)$ and the absorbance of a colored product was read on a spectrophotometer at $412 \mathrm{~nm}$. The concentration of GSH was calculated from a calibration curve prepared by serial dilution of $1 \mathrm{mM}$ stock solution. The results were expressed as $\mu \mathrm{mol} \mathrm{GSH} / \mathrm{g}$ tissue.

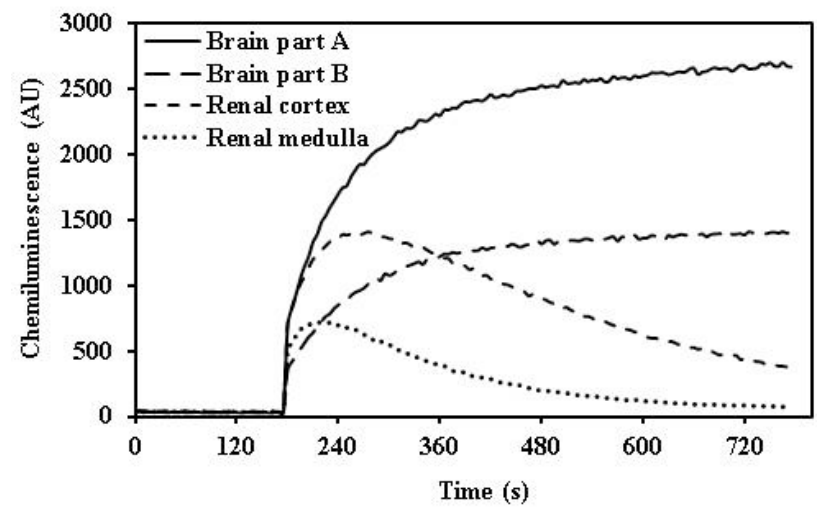

Fig. 1. Time course of NADPH oxidase-mediated $\mathrm{O}_{2}^{-}$production in the brain part $A$ and $B$, renal medulla and cortex.

\section{Statistical analysis}

Results are expressed as mean \pm SEM and the statistical differences between experimental groups were evaluated by Student's t-test. Values of $\mathrm{P} \leq 0.05$ were considered to be statistically significant.

\section{Results}

Table 1 shows significantly higher SBP in threemonth-old Ren-2 TGR than in normotensive HanSD, but the treatment with LOS significantly decreased SBP. Body weights were similar in HanSD and Ren-2 TGR but Ren-2 TGR+LOS were significantly heavier. Hypertension in Ren-2 TGR was accompanied by the increase in absolute and relative heart weight. Treatment with LOS significantly decreased heart weight. Significantly lower relative kidney weight was found in Ren-2 TGR+LOS as compared to untreated animals (Table 1).

Table 2 indicates that there were no significant differences between individual experimental groups in NADPH oxidase-dependent $\mathrm{O}_{2}^{-}$production in brain part A (hypothalamus including PVN) or part B (medulla oblongata with pons including RVLM). However, we obtained enzyme activities, which were nearly twice as high in part A as in part B after 10 min of measurement. To evaluate the degree of brain damage by ROS we 
measured TBARS, conjugated dienes and oxidative index as the indirect markers of lipid peroxidation.
Nevertheless, we did not find any significant differences between the studied groups (Table 2).

Table 1. Basic characteristic of the experimental groups.

\begin{tabular}{llll}
\hline & HanSD & TGR & TGR + LOS \\
\hline Number of rats & 10 & 10 & 10 \\
Systolic blood pressure $(\mathrm{mm} \mathrm{Hg})$ & $133 \pm 5$ & $204 \pm 6 *$ & $144 \pm 7^{\#}$ \\
Body weight $(\mathrm{BW}, \mathrm{g})$ & $489 \pm 10$ & $504 \pm 9$ & $532 \pm 6$ * $^{\#}$ \\
Heart weight $(\mathrm{HW}, \mathrm{g})$ & $1.33 \pm 0.06$ & $1.55 \pm 0.05 *$ & $1.27 \pm 0.02^{\#}$ \\
Kidney weight $(\mathrm{KW}, \mathrm{g})$ & $2.96 \pm 0.11$ & $3.15 \pm 0.07$ & $3.11 \pm 0.06$ \\
Relative heart weight $(\mathrm{HW/BW}, \mathrm{mg} / \mathrm{g})$ & $2.72 \pm 0.10$ & $3.08 \pm 0.10 *$ & $2.39 \pm 0.03 *^{\#}$ \\
Relative kidney weight $(\mathrm{KW} / \mathrm{BW}, \mathrm{mg} / \mathrm{g})$ & $6.04 \pm 0.16$ & $6.32 \pm 0.15$ & $5.85 \pm 0.11^{\#}$ \\
\hline
\end{tabular}

Data are means \pm SEM. Significantly different: ${ }^{*} \mathrm{P}<0.05$ from HanSD rats, ${ }^{*} \mathrm{P}<0.05$ TGR rats. HanSD - Hannover Sprague-Dawley control rats, TGR - transgenic rats (Ren-2), LOS - losartan.

Table 2. Oxidative stress in the brain of experimental groups.

\begin{tabular}{|c|c|c|c|}
\hline & HanSD & TGR & TGR + LOS \\
\hline $\begin{array}{l}\text { NADPH oxidase activity in the brain part } A \\
\left(\text { counts } / \text { mg protein } \times 10^{5}\right)\end{array}$ & $12.32 \pm 0.96$ & $12.24 \pm 0.82$ & $12.98 \pm 0.57$ \\
\hline $\begin{array}{l}\text { NADPH oxidase activity in the brain part B } \\
\left(\text { counts } / \text { mg protein } \times 10^{5}\right)\end{array}$ & $6.95 \pm 0.80$ & $6.09 \pm 0.46$ & $6.25 \pm 0.47$ \\
\hline $\begin{array}{l}\text { TBARS in the brain part } A \\
\text { (nmol/mg protein) }\end{array}$ & $1.22 \pm 0.06$ & $1.24 \pm 0.05$ & $1.29 \pm 0.07$ \\
\hline $\begin{array}{l}\text { TBARS in the brain part } B \\
\text { (nmol/mg protein) }\end{array}$ & $1.78 \pm 0.22$ & $1.68 \pm 0.29$ & $1.31 \pm 0.11$ \\
\hline $\begin{array}{l}\text { Conjugated dienes in the brain part } B \\
\text { ( } \mu \text { mol/g tissue) }\end{array}$ & $1.45 \pm 0.19$ & $1.96 \pm 0.34$ & $1.95 \pm 0.34$ \\
\hline $\begin{array}{l}\text { Oxidative index in the brain part } A \\
\left(A_{233} / A_{215} \text { ratio }\right)\end{array}$ & $0.46 \pm 0.01$ & $0.49 \pm 0.01$ & $0.45 \pm 0.01$ \\
\hline $\begin{array}{l}\text { Oxidative index in the brain part } B \\
\left(A_{233} / A_{215} \text { ratio }\right)\end{array}$ & $0.40 \pm 0.01$ & $0.41 \pm 0.01$ & $0.41 \pm 0.01$ \\
\hline
\end{tabular}

Data are means \pm SEM. HanSD - Hannover Sprague-Dawley control rats, TGR - transgenic rats (Ren-2), LOS - losartan.

Due to a quite different shape of the recorded curves of ROS production in brain and kidney, we evaluated ROS production in renal cortex and medulla for 3 min only (Fig. 1). Contrary to the brain tissue we found significantly elevated NADPH oxidase-dependent $\mathrm{O}_{2}{ }^{-}$ production in both renal cortex and medulla of Ren-2 TGR compared with HanSD (Table 3). The treatment with LOS did not change NADPH oxidase-dependent $\mathrm{O}_{2}{ }^{-}$ production in renal cortex and medulla of Ren-2 TGR. TBARS in renal cortex were significantly elevated in Ren-2 TGR and significantly decreased in Ren-2
TGR+LOS but conjugated dienes and oxidative index did not differ significantly among studied groups. In the renal medulla we did not find any significant differences in TBARS, CD and oxidative index among experimental groups (Table 3).

Concentrations of reduced glutathione (GSH) in renal cortex and medulla (Table 3 ) did not show any significant difference among experimental groups. Similarly, concentrations of GSH in heart and liver were not significantly different among studied groups of rats (Table 4). 
Table 3. Oxidative stress in the kidneys of experimental groups.

\begin{tabular}{|c|c|c|c|}
\hline & HanSD & TGR & TGR + LOS \\
\hline $\begin{array}{l}\text { NADPH oxidase activity in renal cortex } \\
\left(\text { counts } / \mathrm{mg} \text { protein } \times 10^{4}\right)\end{array}$ & $15.85 \pm 1.65$ & $22.38 \pm 1.56^{*}$ & $22.02 \pm 2.37^{*}$ \\
\hline $\begin{array}{l}\text { NADPH oxidase activity in renal medulla } \\
\left(\text { counts } / \text { mg protein } \times 10^{4}\right)\end{array}$ & $9.45 \pm 0.74$ & $12.64 \pm 0.91 *$ & $11.43 \pm 1.66$ \\
\hline$T B A R S$ in renal cortex (nmol/mg protein) & $2.16 \pm 0.21$ & $2.97 \pm 0.25^{*}$ & $2.34 \pm 0.16^{\#}$ \\
\hline TBARS in renal medulla (nmol/mg protein) & $3.33 \pm 0.23$ & $3.32 \pm 0.25$ & $3.22 \pm 0.17$ \\
\hline Conjugated dienes in renal cortex ( $\mu$ mol/g tissue) & $0.67 \pm 0.07$ & $0.66 \pm 0.05$ & $0.69 \pm 0.07$ \\
\hline Conjugated dienes in renal medulla ( $\mu$ mol/g tissue) & $0.68 \pm 0.07$ & $0.64 \pm 0.09$ & $0.65 \pm 0.06$ \\
\hline Oxidative index in renal cortex $\left(A_{233} / A_{215}\right.$ ratio $)$ & $0.54 \pm 0.01$ & $0.54 \pm 0.01$ & $0.55 \pm 0.01$ \\
\hline Oxidative index in renal medulla $\left(A_{233} / A_{215}\right.$ ratio $)$ & $0.30 \pm 0.01$ & $0.31 \pm 0.01$ & $0.31 \pm 0.01$ \\
\hline Thiols in renal cortex ( $\mu$ mol/g tissue) & $4.65 \pm 0.47$ & $4.47 \pm 0.21$ & $5.09 \pm 0.49$ \\
\hline Thiols in renal medulla ( $\mu$ mol/g tissue) & $4.04 \pm 0.33$ & $4.40 \pm 0.54$ & $4.36 \pm 0.36$ \\
\hline
\end{tabular}

Data are means \pm SEM. Significantly different: ${ }^{*} \mathrm{P}<0.05$ from HanSD rats, ${ }^{*} \mathrm{P}<0.05$ TGR rats. HanSD - Hannover Sprague-Dawley control rats, TGR - transgenic rats (Ren-2), LOS - losartan.

Table 4. Oxidative stress in the heart and liver of experimental groups.

\begin{tabular}{|c|c|c|c|}
\hline & HanSD & TGR & TGR + LOS \\
\hline Conjugated dienes in the heart ( $\mu$ mol/g tissue) & $0.59 \pm 0.06$ & $0.60 \pm 0.06$ & $0.60 \pm 0.07$ \\
\hline Thiols in the heart ( $\mu$ mol/g tissue) & $2.55 \pm 0.10$ & $2.51 \pm 0.10$ & $2.53 \pm 0.05$ \\
\hline Thiols in the liver ( $\mu$ mol/g tissue) & $7.35 \pm 0.35$ & $7.97 \pm 0.26$ & $7.98 \pm 0.78$ \\
\hline
\end{tabular}

Data are means \pm SEM. HanSD - Hannover Sprague-Dawley control rats, TGR - transgenic rats (Ren-2), LOS - losartan.

\section{Discussion}

Our present study shows new data on NADPH oxidase-dependent $\mathrm{O}_{2}^{-}$production and oxidative damage in two parts of the brain, which are essential for BP control, and in renal cortex and medulla of Ren-2 TGR with angiotensin II-dependent hypertension.

We confirmed higher SBP in 3-month-old Ren-2 TGR compared with age-matched normotensive HanSD. We found a good correspondence between SBP elevation in our present study and the earlier studies, which followed Ren-2 TGR over a wide spectrum of age ranging from 15-69 weeks (Kasper et al. 2005, Nautiyal et al. 2012a). Losartan treatment lowered SBP as has been shown in the previous studies (Stula et al. 1998, Teisman et al. 1998, Zhou et al. 1999, Rakusan et al. 2010).

We did not find significantly higher body weight of Ren-2 TGR compared to HanSD as reported by Nautiyal et al. (2012a) in 25-week-old animals. We observed a significant increase of body weight in Ren-2 TGR after LOS treatment that was consistent with valsartan treated 6-week-old Ren-2 TGR (30 mg/kg/day for 21 days) in the study of Whaley-Connell et al. (2006). The significantly higher heart-to-body weight ratio in Ren-2 TGR indicates the severity of hypertension.

We did not find any difference in the activity of NADPH oxidase-dependent $\mathrm{O}_{2}^{-}$production in the brain part A or part B among experimental groups. Nautiyal et al. (2012a) described significantly higher NADPH oxidase activity of brain dorsal medullary tissue in 25-week-old Ren-2 TGR compared with age-matched HanSD controls. Thus, the different results of our study could be related to substantially younger age of our animals. Higher NADPH oxidase activity in brain dorsal medullary tissue was significantly reduced by two weeks of intracerebroventricular infusion of ROS scavenger tempol (cell-permeable superoxide dismutase mimetic). On the other hand, the infusion of artificial cerebrospinal fluid or candesartan (angiotensin II type 1 receptor 
antagonist) had no significant effect on brain NADPH oxidase activity (Nautiyal et al. 2012b).

As far as the kidney is concerned, NADPH oxidase is the primary source of $\mathrm{O}_{2}{ }^{-}$under physiological conditions (Kitiyakara et al. 2003, Chen et al. 2005). We found significant elevation of NADPH oxidase-dependent $\mathrm{O}_{2}{ }^{-}$production in both cortex and medulla of Ren-2 TGR. Similarly, the studies in young (6-week-old) TGR described the elevation of renal NADPH oxidasedependent $\mathrm{O}_{2}^{-}$production as compared with age-matched Sprague-Dawley controls (Whaley-Connell et al. 2008, Whaley-Connell et al. 2009). The increased renal NADPH oxidase activity of Ren-2 TGR was in concert with the enhancement of NADPH oxidase subunit expression and oxidative stress markers. These changes were also associated with structural changes in kidney (Whaley-Connell et al. 2006, 2008). Our results of increased NADPH activity in both parts of the kidney in Ren-2 TGR are partially in contrast to our previous results in salt-hypertensive Dahl rats in which NADPH activity was increased only in medulla (Vokurková et al. 2015). This contradictory finding could be related to higher RAS-dependent activation of ROS production in Ren-2 TGR, which have angiotensin II-dependent hypertension with increased activity of endogenous RAS.
Glutathione, a tripeptide present in all tissues, is involved in various detoxification mechanisms. It also serves as a scavenger of free radicals (Sies 1999, Aquilano et al. 2014). Intracellular content of GSH was different in the examined tissues but it was not influenced by genotype or LOS treatment.

In summary, the present study shows increased NADPH oxidase activities only in renal cortex and medulla with significantly increased TBARS in renal cortex. No significant changes were detected in the studied brain regions.

\section{Conflict of Interest}

There is no conflict of interest.

\section{Acknowledgements}

The authors would like to thank to Alena Charvátová, Zdeňka Kopecká, Iva Nahodilová and Marie Schützová, for their excellent technical assistance. This work was supported by research grant 304/12/0259 (Czech Science Foundation), 15-25396A by Ministry of Health of the Czech Republic, ERDF, OPPK Biomodels CZ.2.16/3.1.00/24017 and RVO: 67985823 (Institute of Physiology).

\section{References}

AQUILANO K, BALDELLI S, CIRIOLO MR: Glutathione: new roles in redox signaling for an old antioxidant. Front Pharmacol 5: 196, 2014.

CHAN SH, CHAN JY: Brain stem NOS and ROS in neural mechanisms of hypertension. Antioxid Redox Signal 20: 146-163, 2014.

CHEN Y, GILL PS, WELCH WJ: Oxygen availability limits renal NADPH-dependent superoxide production. $A m J$ Physiol Renal Physiol 289: F749-F753, 2005.

CROWLEY SD, COFFMAN TM: The inextricable role of the kidney in hypertension. J Clin Invest 124: 2341-2347, 2014.

DATLA SR, GRIENDLING KK: Reactive oxygen species, NADPH oxidases, and hypertension. Hypertension 56: 325-330, 2010.

ELLMAN GL: Tissue sulfhydryl groups. Arch Biochem Biophys 82: 70-77, 1959.

GABOR A, LEENEN FH: Central neuromodulatory pathways regulating sympathetic activity in hypertension. $J$ Appl Physiol 113: 1294-1303, 2012.

GRIENDLING KK, SORESCU D, USHIO-FUKAI M: NAD(P)H oxidase: role in cardiovascular biology and disease. Circ Res 86: 494-501, 2000.

GUYENET PG: The sympathetic control of blood pressure. Nat Rev Neurosci 7: 335-346, 2006.

HARRISON DG, GONGORA MC: Oxidative stress and hypertension. Med Clin North Am 93: 621-635, 2009.

HIROOKA Y, KISHI T, SAKAI K, TAKESHITA A, SUNAGAWA K: Imbalance of central nitric oxide and reactive oxygen species in the regulation of sympathetic activity and neural mechanisms of hypertension. Am J Physiol Regul Integr Comp Physiol 300: R818-R826, 2011. 
KAPLÁN P, DOVAL M, MAJEROVÁ Z, LEHOTSKÝ J, RACAY P: Iron-induced lipid peroxidation and protein modification in endoplasmic reticulum membranes. Protection by stobadine. Int $J$ Biochem Cell Biol 32: 539-547, 2000.

KASPER SO, CARTER CS, FERRARIO CM, GANTEN D, FERDER LF, SONNTAG WE, GALLAGHER PE, DIZ DI: Growth, metabolism, and blood pressure disturbances during aging in transgenic rats with altered brain renin-angiotensin systems. Physiol Genomics 23: 311-317, 2005.

KASPER SO, FERRARIO CM, GANTEN D, DIZ DI: Rats with low brain angiotensinogen do not exhibit insulin resistance during early aging. Endocrine 30: 167-174, 2006.

KITIYAKARA C, CHABRASHVILI T, CHEN Y, BLAU J, KARBER A, ASLAM S, WELCH WJ, WILCOX CS: Salt intake, oxidative stress, and renal expression of NADPH oxidase and superoxide dismutase. J Am Soc Nephrol 14: $2775-2782,2003$.

KLEIN RA: The detection of oxidation in liposome preparations. Biochim Biophys Acta 210: 486-489, 1970.

KOGURE K, WATSON B, BUSTO R, ABE K: Potentiation of lipid peroxides by ischemia in rat brain. Neurochem Res 7: 437-454, 1982.

LOWRY OH, ROSEBROUGH NJ, FARR AL, RANDALL RJ: Protein measurement with the Folin phenol reagent. J Biol Chem 193: 265-275, 1951.

MATSUI H, SHIMOSAWA T, UETAKE Y, WANG H, OGURA S, KANEKO T, LIU J, ANDO K, FUJTA T: Protective effect of potassium against the hypertensive cardiac dysfunction: association with reactive oxygen species reduction. Hypertension 48: 225-231, 2006.

MULLINS JJ, PETERS J, GANTEN D: Fulminant hypertension in transgenic rats harbouring the mouse Ren-2 gene. Nature 344: 541-544, 1990.

NAUTIYAL M, KATAKAM PV, BUSIJA DW, GALLAGHER PE, TALLANT EA, CHAPPELL MC, DIZ DI: Differences in oxidative stress status and expression of MKP-1 in dorsal medulla of transgenic rats with altered brain renin-angiotensin system. Am J Physiol Regul Integr Comp Physiol 303: R799-R806, $2012 \mathrm{a}$.

NAUTIYAL M, SHALTOUT HA, DE LIMA DC, Do NASCIMENTO K, CHAPPELL MC, DIZ DI: Central angiotensin-(1-7) improves vagal function independent of blood pressure in hypertensive (mRen2)27 rats. Hypertension 60: 1257-1265, $2012 \mathrm{~b}$.

NGUYEN DINH CAT A, MONTEZANO AC, BURGER D, TOUYZ RM: Angiotensin II, NADPH oxidase, and redox signaling in the vasculature. Antioxid Redox Signal 19: 1110-1020, 2013.

OHKAWA H, OHISHI N, YAGI K: Assay for lipid peroxides in animal tissues by thiobarbituric acid reaction. Anal Biochem 95: 351-358, 1979.

PARAVICINI TM, TOUYZ RM: NADPH oxidases, reactive oxygen species, and hypertension: clinical implications and therapeutic possibilities. Diabetes Care 31 (Suppl 2): S170-S180, 2008.

PAXINOS G, WATSON C: The Rat Brain in Stereotaxic Coordinates. Elsevier Academic Press, Amsterdam, 2005.

PETERSON JR, SHARMA RV, DAVISSON RL: Reactive oxygen species in the neuropathogenesis of hypertension. Curr Hypertens Rep 8: 232-241, 2006.

RAKUSAN D, KUJAL P, KRAMER HJ, HUSKOVÁ Z, VANOURKOVÁ Z, VERNEROVÁ Z, MRÁZOVÁ I, THUMOVÁ M, CERVENKA L, VANECKOVÁ I: Persistent antihypertensive effect of aliskiren is accompanied by reduced proteinuria and normalization of glomerular area in Ren-2 transgenic rats. Am J Physiol Renal Physiol 299: F758-F766, 2010.

SIES H: Glutathione and its role in cellular functions. Free Radic Biol Med 27: 916-921, 1999.

STULA M, PINTO YM, GSCHWEND S, TEISMAN AC, VAN GILST WH, BÖHM M, DIETZ R, PAUL M: Interaction of the renin-angiotensin system and the endothelin system in cardiac hypertrophy. $J$ Cardiovasc Pharmacol 31 (Suppl 1): S403-S405, 1998.

TEISMAN AC, PINTO YM, BUIKEMA H, FLESCH M, BÖHM M, PAUL M, VAN GILST WH: Dissociation of blood pressure reduction from end-organ damage in TGR(mREN2)27 transgenic hypertensive rats. J Hypertens 16: 1759-1765, 1998.

VAŇOURKOVÁ Z, KRAMER HJ, HUSKOVÁ Z, ČERVENKA L, VANĚČKOVÁ I: Despite similar reduction of blood pressure and renal ANG II and ET-1 levels aliskiren but not losartan normalizes albuminuria in hypertensive Ren-2 rats. Physiol Res 59: 339-345, 2010. 
VOKURKOVÁ M, RAUCHOVÁ H, ŘEZÁČOVÁ L, VANĚČKOVÁ I, ZICHA J: ROS production is increased in the kidney but not in the brain of Dahl rats with salt hypertension elicited in adulthood. Physiol Res 64: 303-312, 2015.

WHALEY-CONNELL AT, CHOWDHURY NA, HAYDEN MR, STUMP CS, HABIBI J, WIEDMEYER CE, GALLAGHER PE, TALLANT EA, COOPER SA, LINK CD, FERRARIO C, SOWERS JR: Oxidative stress and glomerular filtration barrier injury: role of the renin-angiotensin system in the Ren2 transgenic rat. $A m J$ Physiol Renal Physiol 291: F1308-F1314, 2006.

WHALEY-CONNELL A, HABIBI J, NISTALA R, COOPER SA, KARUPARTHI PR, HAYDEN MR, REHMER N, DEMARCO VG, ANDRESEN BT, WEI Y, FERRARIO C, SOWERS JR: Attenuation of NADPH oxidase activation and glomerular filtration barrier remodeling with statin treatment. Hypertension 51: 474-480, 2008.

WHALEY-CONNELL A, HABIBI J, WEI Y, GUTWEILER A, JELLISON J, WIEDMEYER CE, FERRARIO CM, SOWERS JR: Mineralocorticoid receptor antagonism attenuates glomerular filtration barrier remodeling in the transgenic Ren2 rat. Am J Physiol Renal Physiol 296: F1013-F1022, 2009.

ZHUO J, OHISHI M, MENDELSOHN FA: Roles of $\mathrm{AT}_{1}$ and $\mathrm{AT}_{2}$ receptors in the hypertensive Ren-2 gene transgenic rat kidney. Hypertension 33: 347-353, 1999. 